\title{
« No barricado for a belly »: Shakespeare et l'érotique de la ville
}

\section{Sophie Chiari}

\section{(2) OpenEdition}

\section{Journals}

\section{Édition électronique}

URL : http://journals.openedition.org/shakespeare/1597

DOI : 10.4000/shakespeare.1597

ISSN : 2271-6424

\section{Éditeur}

Société Française Shakespeare

\section{Édition imprimée}

Date de publication : 1 mars 2011

Pagination : $3-26$

ISBN : 2-9521475-7-4

\section{Référence électronique}

Sophie Chiari, « « No barricado for a belly » : Shakespeare et l'érotique de la ville », Actes des congrès de la Société française Shakespeare [En ligne], 28 | 2011, mis en ligne le 15 février 2011, consulté le 19 avril 2019. URL : http://journals.openedition.org/shakespeare/1597 ; DOI : 10.4000/shakespeare.1597 


\section{Shakespeare et la Cité}

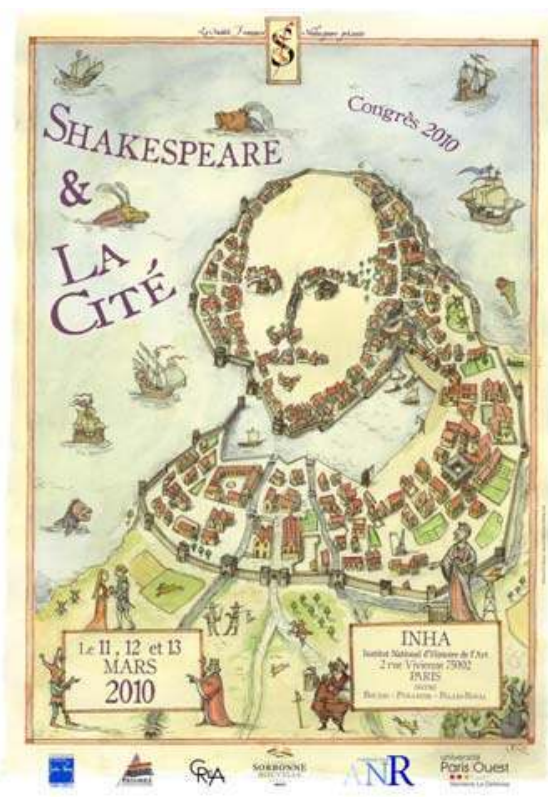

actes du Congrès

organisé par la

SOCIÉTÉ FRANÇAISE SHAKESPEARE

les 11,12 et 13 mars 10

textes réunis par

Pierre KAPITANIAK

sous la direction de

Dominique GoY-BLANQUET 
COUVERTURE :

Edouard Lekston 2010

conception graphique et logo

Pierre Kapitaniak

\section{(C) 2011 Société Française Shakespeare Institut du Monde Anglophone} Université de Paris III - Sorbonne Nouvelle 5 rue de l'École de Médecine 75006 Paris

www.societefrancaiseshakespeare.org réservés pour tous les pays 


\title{
« NO BARRICADO FOR A BELLY1 》: SHAKESPEARE ET L'ÉROTIQUE DE LA VILLE
}

\author{
Sophie CHIARI
}

Dans l'œuvre de Shakespeare, le corps des femmes est souvent assimilé à des cités assiégées. Cet article se propose d'étudier la ville shakespearienne par le biais de ses personnages féminins, en commençant par la ville et ses tentations à travers Bacon, Dekker, Jonson, Nashe ou Peend, afin de mieux comprendre, dans un second temps, la nature ambiguë des liens qu'entretient la cité renaissante avec la notion de chasteté. Enfin, l'accent sera mis sur l'importance du rôle de la cité pour ces maîtresses femmes qui, loin d'être victimes de la concupiscence des hommes, prennent au contraire du plaisir à éveiller leurs sens.

In Shakespeare's work, women's bodies are repeatedly assimilated to assailed or besieged cities. This paper addresses the issue of the Shakespearian city viewed through his female characters. The town and its temptations are here presented throughout Bacon, Dekker, Jonson, Nashe or Peend, then lead to a scrutiny of the somewhat ambiguous nature of the city/chastity relationship before eventually analyzing the role played by the city for women who, far from being victims, took pleasure and/or profit in arousing men's lust.

A début du XvII ${ }^{\mathrm{e}}$ siècle, Tommaso Campanella, contemporain $\triangle$ de Shakespeare, imagine une cité utopique, La cité du soleil 1 (1602), dans laquelle Amour préside à un système obligatoire d'éducation et d'apprentissage, et veille à l'application pratique d'une politique d'eugénisme. La continence sexuelle est exigée jusqu'à dixneuf ans pour les filles, jusqu'à vingt et un ans pour les garçons. Les sentiments amoureux sont bannis. S’il existe bien dans la cité quelques lupanars accessibles aux individus incapables de réfréner leurs pulsions, les relations sexuelles obéissent à un strict impératif de reproduction. Les partenaires «ne s'accouplent que digestion faite et après avoir prié ${ }^{2}$ ", afin d'engendrer des enfants parfaitement sains de corps et d'esprit.

Chez son prédécesseur Thomas More, l'acte sexuel en tant qu'expression d'une passion individuelle au sein de la cité était déjà considéré comme un acte de transgression : " une fille ou un garçon convaincus d'amours clandestines sont sévèrement punis et tout mariage leur est dorénavant interdit ». Les parents des coupables sont

\footnotetext{
${ }^{1}$ The Winter's Tale, I.ii.202, ed. Stephen Orgel, Oxford, O.U.P., 1996.

2 Tommaso Campanella, La cité du soleil, éd. Luigi Firpo, trad. Arnaud Tripet, Genève, Droz, 1972, p. 20.
} 
également châtiés pour avoir «négligé leurs devoirs ». Enfin, toute récidive est «punie de mort ${ }^{3}$. »

Qu'en est-il au juste de Shakespeare et de ses contemporains ? Quels liens peut-on établir entre le texte dramatique et la réalité londonienne des XVI et XVII e siècles? Shakespeare fait du corps une métaphore de la cité. La charpente de l'amoureux est comparée à un bâtiment qui menace de s'effondrer dès que son amour se fragilise. Ainsi, dans The Two Gentlemen of Verona, Valentin souhaite le retour de l'absente, Silvia, « Lest, growing ruinous, the building fall » (v.iv.710) ${ }^{4}$. On retrouve une image analogue dans The Comedy of Errors 5 . Le corps de la femme est assimilé à la cité tout entière, quand ce n'est pas aux pays décrits par Dromio de Syracuse qui, dans The Comedy of Errors, transforme Nell, la cuisinière, en une gigantesque mappemonde à la fois érotique et parodique (III.ii.111-52).

J'aborderai le thème de la cité chez Shakespeare à travers ses personnages féminins, en m'intéressant tout d'abord à la ville et aux tentations qu'elle suppose, avant de voir comment la cité peut aussi renvoyer à la chasteté. Je terminerai en étudiant le rôle joué par la cité chez ces maitresses-femmes qui, loin d'être des victimes, prennent plaisir à attiser la convoitise des hommes.

\section{La ville et ses tentations}

À la Renaissance, la ville prend de l'importance. Aux XVI et XVII siècles, la population de Londres décuple et la ville devient l'une des grandes métropoles occidentales. En 1599, Thomas Dekker fait même de sa ville natale le cadre privilégié d'une pièce intitulée The Shoemaker's Holiday, qui met en scène l'ascension d'un maître cordonnier promu maire de Londres et qui, incidemment, est aussi "l'une des premières comédies anglaises à planter résolument son décor au beau milieu de la City ${ }^{6}$. » Curieusement, la cité y est à la fois

\footnotetext{
3 Thomas More, L'utopie (1516), Paris, Flammarion, 1987, p. 191.

${ }^{4}$ Sauf précision contraire, les citations de Shakespeare seront extraites de William Shakespeare, The Complete Works, éds. Stanley Wells and Gary Taylor, Oxford, Clarendon Press, 1988.

5 «Shall love in building grow so ruinous?» (III.ii.4) s'exclame Luciana en désignant Antipholus de Syracuse. Voir William Shakespeare, The Comedy of Errors, éd. R. A. Foakes, Londres, The Arden Shakespeare, (1968), 1980.

${ }^{6}$ François Laroque, «Le Londres en fête de Thomas Dekker dans The Shoemaker's Holiday ", in Les représentations de Londres (2), Actes du colloque tenu à l'Université de
} 
corporalisée et sexualisée, et «l'évocation d'un clocher-phallus fécondant une fontaine féminisée ${ }^{7}$ » donne à l'espace citadin un caractère à la fois grotesque et inquiétant. La ville mi-réaliste, miimaginaire de Dekker incite les spectateurs à mieux la connaitre : c'est à ce prix qu'elle leur donnera tout le plaisir attendu.

L'attraction de la cité bat donc son plein et, selon Francis Bacon, elle fait partie de ce que tout voyageur doit connaître :

The things to be seen and observed are : the courts of princes, especially when they give audience to ambassadors; the courts of justice, while they sit and hear causes; and so of consistories ecclesiastic; the churches and monasteries, with the monuments which are therein extant; the walls and fortifications of cities, and towns, and so the heavens and harbors ; [...] houses and gardens of state and pleasure, near great cities ; [...] and, to conclude, whatsoever is memorable, in the places where they go $^{8}$.

Pourtant, s'il faut connaître la ville, il n'est pas bon d'y résider trop longtemps :

Let him not stay long, in one city or town ; more or less as the place deserveth, but not long ; nay, when he stayeth in one city or town, let him change his lodging from one end and part of the town, to another ; which is a great adamant of acquaintance.

À croire que Shelton et Heyden, les protagonistes du Famous Voyage (1612) de Ben Jonson ${ }^{9}$, ont lu Bacon car ils appliquent à la lettre les conseils prodigués dans les Essais. Dans ce poème satirique, les héros se mettent en tête de parcourir les grandes cités européennes et comptent bien visiter Londres :

[...] in worthy scorne

Of those, that put out moneyes, on returne

From Venice, Paris, or some in-land passage

Of sixe times to, and fro, without embassage,

Or him that backward went to Berwicke, or which

Did dance the famous Morrisse, unto Norwich.

Bordeaux III les 9 et 10 mars 1984, Annales du GERB sous la direction de Michel Jouve et Marie-Claire Rouyer, Bordeaux, 1984, p. 7.

7 Ibid., p. 21.

8 Francis Bacon, « Of Travel», Essays, 1601. Voir le site Internet: http://oregonstate.edu/instruct/phl302/texts/bacon/bacon essays.html.

${ }^{9}$ Toutes les références au poème de Jonson sont extraites de Ben Jonson, éds. C. H. Herford, Percy et Evelyn Simpson (11 vols., Oxford, Clarendon, 1954-70) vol. 8. Voir aussi le texte disponible sur le site Internet: http://www.sewerhistory.org/misc/jonson2.htm. 
De tels pèlerinages sont des grands classiques de l'époque. On pense en particulier aux exploits dûment rémunérés de Sir Robert Carey, qui mit douze jours pour aller de Berwick à Londres en 1589, et à ceux de William Kempe, célèbre clown qui quitta en 1599 la troupe de théâtre de Shakespeare et en profita pour danser la moresque tout au long du parcours de Londres à Norwich ${ }^{10}$.

Alors que dans son œuvre, Shakespeare privilégie l'évasion ${ }^{11}$ et recourt à une esthétique du détour pour critiquer ses contemporains, Jonson, en adepte de la " city comedy ", s'apprête dans le passage cité à décrire Londres sous toutes ses coutures. Alors que ses héros persistent dans leur épopée burlesque et s'aventurent au cœur de la cité en naviguant sur la Tamise, la ville anthropomorphe devient un corps grotesque - le corps d'une gigantesque prostituée :

Thorough her wombe they make their famous road,

Betweene two walls ; where, on one side, to scar men,

Were seene your ugly Centaures, yee call Car-men,

Gorgonian scolds, and Harpyes : on the other

Hung stench, diseases, and old filth, their mother,

With famine, wants, and sorrowes many a dosen,

The least of which was to the plague a cosen.

En se faufilant dans les recoins les plus sordides de Londres, les héros découvrent en réalité les aspects les plus rebutants du corps féminin et, selon Andrew McRae, Jonson signe là une critique sévère des vicissitudes londoniennes et de la débauche féminine :

In the "wombe" of the city-whore, conventional images of generation and familial identity undergo a sea-change. The "mother" of "stench" and "diseases" is merely "old filth ;" "famine, wants, and sorrowes" are "cosen(s)" to the plague. At the end of the section, Jonson exploits a pun on "sink," which is a receptacle for waste or sewage, and in the body an organ of digestion and excretion. In the female body, the signification of "a place where things are swallowed up or lost" extends to the vagina (a sense exploited in The Faerie Queene); and this usage aligns with instances of "sink" denoting a whore or brothel. An implicit threat throughout the journey is the pox, which was itself perceived as "flowing matter" which could move around the body ${ }^{12}$.

\footnotetext{
${ }^{10}$ William Kemp, Kemps Nine Daies Wonder : Performed in a Daunce, éd. Alexander Dyce, Londres, 1839.

${ }^{11}$ Exception faite des Merry Wives of Windsor.

12 Andrew McRae, «'On the Famous Voyage': Ben Jonson and Civic Space», EMLS, ${ }^{\circ}{ }_{3}$, septembre 1998, 8.1-31. Voir le site : http://extra.shu.ac.uk/emls/o4-2/mcraonth.htm.
} 
La cité peut donc être un immense piège où tombent les jeunes gens désœuvrés. Lorsque, dans Twelfth Night, Antonio donne rendezvous à Sébastien «In the south suburbs at the Elephant » (III.iii.39), on voit par exemple s'esquisser assez nettement les contours des faubourgs de Londres. L' « Éléphant » était en effet une auberge bien réelle du Bankside. Et, dans ces faubourgs, les lieux de débauche (ou «nunneries $\left.{ }^{13} »\right)$ côtoient les théâtres, de sorte que les relations troubles qu'entretiennent les deux amis pourraient bien s'y épanouir. Antonio fait d'ailleurs déjà miroiter quelque petit cadeau à Sébastien :

Haply your eye shall light upon some toy

You have desire to purchase...

(III.iii.44-45)

Shakespeare se borne toutefois à suggérer cette possibilité puisque Sébastien n'hésitera pas à délaisser ses amours masculines pour les beaux yeux d'Olivia, cela loin de la ville et de ses tentations.

La cité, en effet, est un lieu centripète avant d'être centrifuge. On veut la connaître avant de souhaiter la quitter, à l'instar de Timon d'Athènes qui, encourageant Alcibiade à détruire Athènes ${ }^{14}$, ne condamne pas seulement la corruption généralisée de la cité et de la chair (IV.iii), mais l'univers tout entier qu'il voue à la destruction. Sur un mode plus léger, que l'on songe un instant au héros de Nashe dans son poème érotique, The Choise of Valentines : ce dernier vient à la ville pour y retrouver son amie dans un lupanar sordide. Il y découvrira un plaisir féminin insatiable et devra dès lors se résoudre à constater ses propres limites face à l'inventivité de sa compagne ${ }^{15}$.

Rien de surprenant, donc, à ce que les mésaventures de jeunes hommes ignorants aient représenté une source d'inspiration constante pour les Élisabéthains. En 1565, lorsque le jeune Thomas Peend publie son épyllion intitulé The Pleasant Fable of Hermaphroditus and Salmacis $^{16}$, il est avocat à la cour et connaît donc bien les vices des

\footnotetext{
13 Voir Hamlet III.i.123 : "Get thee to a nunnery. Why wouldst thou be a breeder of sinners?»

${ }^{14}$ Sur la misanthropie de Timon, voir les remarques de Pierre Brunel, Claudel et Shakespeare, Librairie Armand Colin, Paris, 1971, p. 69, ainsi que l'article de François Laroque, "Entropie et misanthropie dans Timon d'Athènes », Méthode!, nº 13 , automne 2007, p. 353-63.

${ }^{15}$ Sur le poème de Nashe, voir aussi «City Limits : Nashe's Choise of Valentines and Jonson's Famous Voyage », The Review of English Studies, n ${ }^{\circ}$ 56, 2005, p. 247-262.

${ }^{16}$ Reproduit dans Renaissance Tales of Desire. Hermaphroditus and Salmacis, Theseus and Ariadne, Ceyx and Alcione, éd. Sophie Chiari, Cambridge, CSP, 2009, p. 34-69.
} 
Londoniens et, peut-être aussi, ceux des Londoniennes. Sa réécriture d'un épisode célèbre des Métamorphoses d'Ovide se double donc d'un récit didactique qui met en scène un beau mais naif jeune homme, Hermaphrodite, parti de sa campagne natale pour découvrir la ville :

\author{
[...] thear, full fyftene yeres \\ hys lyfe also hee led. \\ And then desyrous for to know \\ the state of countreys straunge, \\ All Licia land, by trauayle great \\ to Caria $^{17}$ he dyd range.
}

La Carie désigne ici symboliquement la ville de Londres. Le jeune homme y rencontrera par hasard Salmacis, nymphe ovidienne ou prostituée londonienne, qui n'hésitera pas à jeter son dévolu sur lui. James Richard Ellis voit dans cette réécriture moralisatrice une mise en garde très claire contre les dangers de la cité :

Bearing in mind the Inns of Court milieu, the poem's moral becomes only too obvious and appropriate: Hermaphroditus is the naïve youth from the country, newly arrived at the Inns, to become a lawyer or a courtier, and in danger of being overwhelmed by the alluring vices of the great city, "the world where all temptations be ${ }^{18 "}$.

Thomas Peend donne en effet la clé de sa fable dans la deuxième partie de son texte, et explique ce qu'il entend par Carie, sans toutefois nommer Londres de manière explicite :

By Caria, sygnyfye the worlde

where all temptations be.

Wheras the good and il, alwayes

together we may see.

L'interprétation d'Ellis paraît d'autant plus convaincante qu'Hermaphrodite serait selon lui le double d'un auteur utilisant sa

\footnotetext{
${ }^{17}$ Voir la note éditoriale de Renaissance Tales of Desire, op. cit., note 16, p. 40 : «In ancient times the coast and the hinterland of Asia Minor were divided into provinces that owed their origins to the indigenous population or to the peoples who had colonized them. In many cases it is difficult to determine whether an area took its name from the indigenous population or from the colonists or, as is often the case, from a combination of the two. Caria is one of those regions whose origins are uncertain since contradictory evidence and ancient commentaries give us no definitive answer. Herodotus (484-425 BC) tells us that the Carians were originally from the Greek Islands, subjects of King Minos of Crete, that they were great seafarers and fighters who manned the Minoan fleets. »

18 James Richard Ellis, Sexuality and Citizenship : Metamorphosis in Elizabethan Erotic Verse, Toronto, University of Toronto Press, 2003, p. 50.
} 
propre expérience pour dresser son portrait en creux dans la fable ovidienne : "[l]ike the young Inns of Court gallant, Hermaphroditus is insufficiently guarded against his own desires, and his masculinity becomes hopelessly compromised or metamorphosed ${ }^{19}$. " La ville est donc le lieu de tous les dangers, de toutes les séductions, le lieu des plaisirs faciles et des ennuis durables, où des femmes dépravées causent la perte de jeunes gens inexpérimentés.

Les femmes n'ont donc pas spécialement le beau rôle dans la cité londonienne du Xvi ${ }^{\mathrm{e}}$ siècle, et restent sujettes aux préjugés de la société patriarcale de leur temps. Il serait toutefois réducteur de ne voir en elles que de simples victimes. Intéressons-nous quelques instants à Une lettre envoyée par des vierges londoniennes (A Letter sent by the Maydens of London $^{20}$ ), opuscule publié en 1567 et qui met en scène six jeunes femmes (Rose, Jane, Rachell, Sara, Philumias et Dorothy) issues d'un milieu assez pauvre, mais qui revendiquent leurs droits et leur liberté en se moquant des conceptions erronées et arriérées d'une certain Edward Hake. Leur lettre est en effet écrite en réaction contre ce jeune homme traducteur d'Érasme et auteur de The Mery Meeting of Maydens in London, publié plus tôt la même année, en 1567. Son ouvrage, aujourd'hui perdu, était une attaque en règle contre la lascivité et la paresse des ménagères londoniennes. La lettre des six vierges répondant à cette attaque aurait pu être l'œuvre d'une femme issue du peuple, si l'on en juge par les connaissances très précises de l'auteur sur l'univers féminin et plus précisément sur les servantes de son époque. Mais le texte est également émaillé de références aux lois en vigueur et, à l'époque, aucune femme n'avait accès à de telles connaissances. L'auteur est donc vraisemblablement un homme et se meut avec aisance aussi bien dans l'univers domestique des servantes londoniennes que dans la sphère publique des hommes de loi. Il est parfois d'une ironie mordante lorsqu'il perce à jour les véritables desseins de Hake le bien-pensant, lequel passe son temps à observer les Londoniennes sous couvert d'une critique acerbe des mœurs de ses contemporaines :

\footnotetext{
19 Ibid.

${ }^{20}$ Voir Kirby Farrell, Elizabeth H. Hageman et Arthur F. Kinney (éds.), Women in the Renaissance. Selections from English Literary Renaissance, Amherst, The University of Massachusetts Press, (1971) 1988, p. 36-47 ; (la lettre est commentée par R. J. Fehrenbach).
} 
And where he alleageth that we doe mispend our time in the Church in gazing and looking about us, and that our comming thither is not to pray: surely he himself was not very well occupied in the Church, and prayed but little (as it seemeth) when he stood gazing and looking about him at us, to marke what we didde. (sig. A6)

La lettre prêche donc la cause des jeunes Londoniennes de condition modeste, et son auteur y affirme même avec véhémence que les parents ne devraient pas forcer les filles à épouser un homme qu'elles n'ont pas choisi. L'amour, selon lui, devrait être la cause principale du mariage (sig. B2) - le conditionnel suffisant à montrer le peu de cas que l'on faisait alors des desiderata féminins.

Shakespeare reflète cet état de fait dans Romeo and Juliet, où l'héroïne est traitée avec la plus grande cruauté par son père parce qu'elle ose choisir l'homme qui partagera sa vie. " [H]ang, beg, starve, die in the streets ! » (III.v.192), lui lance le vieux Capulet excédé lorsque sa fille refuse le parti qu'il lui propose. On comprend mieux l'insupportable violence que doit endurer Juliette, menacée d'être réduite à l'errance dans les bas-quartiers de Vérone, la rue devenant alors pour la femme synonyme de déchéance et de prostitution.

Si Shakespeare dénonce la violence du père avec ses jeux de mots aussi grivois qu'incongrus sur sa propre fille, qu'il menace d'abandonner dans les rues de la ville, il sait aussi pourfendre les citadines frivoles. À l'opposé des discours misérabilistes sur la condition féminine, on trouve donc aussi des attaques en règle contre le sexe faible. Ainsi, dans As You Like It, Jacques s'interroge sur les coquetteries de la gent féminine :

What woman in the city do I name

When that I say the city-woman bears

The cost of princes on unworthy shoulders? (II.vii.74-76)

Comme le constate Michael Hattaway, la remarque de Jacques fait écho à celle de Thomas Platter qui, visitant Londres en 1599, s'étonnait des habits luxueux portés par les femmes, alors même que les lois somptuaires étaient en vigueur ${ }^{21}$.

${ }^{21}$ William Shakespeare, As You Like It, ed. Michael Hattaway, Cambridge, C.U.P., 20oo, p. 120. Pour les observations de Thomas Platter, Voir Thomas Platter's Travels in England (1599), Clare Williams, 1937, p. 183. Sur les lois somptuaires, voir l'étude de Wilfrid Hooper, «The Tudor Sumptuary Laws », The English Historical Review, vol. 30, n 119 juillet 1915, p. 433-49 (p. 444): "Fashion [...] was stronger than law, and apparel continued to overstep its appointed bounds in a manner that alarmed the government into 
En effet, les citadines sortent, se montrent, s'habillent avec extravagance si leurs moyens le leur permettent, et s'exposent de ce fait à la critique, elles qui devraient prendre modèle sur la chaste Pénélope et s'adonner à l'activité du tissage au sein du foyer. En 1566, Thomas Underdowne écrivait ainsi dans la préface de son ouvrage, The Excellent Historie of Theseus and Ariadne :

Yon ydle Dames whersoever yon be, tell me I praye you ? what was the cause that Penelope was so muche honoured in her tyme, and left eternal memorie of her good renowne to us after her death ? What trade of lyfe led shee when Ulysses was at the Siege of Troye ? shee beynge a Quene dyd paynfullye spyn and keepe her howse, and for all the knot of gentell Woers that she had, she never left her worke to dallye and toye with them, thoughe her Husband were awaye .xx. yeares. What dyd the wicked Tarquyne fynde the good Ladye Lucres doynge when he came to ravyshe her? If ye knowe not (O ye amourous Ladyes to you I speake) I wyll tell you: she sat spynnyge with her Maydes: and beyng deflowered: she neither gave Tarquyne thankes for his good wyll, nor reward for his paynes, but slewe her selfe, because her Husbandes bedde was defyled. Let these to Ladyes be Examples, to you (O ye Ladyes enamorous) howe you shall occupye your selves in your Howses $^{22} \ldots$

Tisser, coudre et broder sont des activités à encourager, parce qu'elles forcent les femmes à rester chez elles. De tels relents de misogynie prouvent à quel point elles étaient indésirables dans les rues de la cité. Hors les murs du foyer, point de salut. Pourtant, le texte de Thomas Underdowne montre aussi que la gent féminine s'enhardit peu à peu : si les femmes restaient sagement cloîtrées chez elles, l'auteur ne ressentirait sans doute pas le besoin de rédiger ces lignes outrancières.

Les bourgeoises qui s'exposent au regard désapprobateur des puritains revendiquent simplement une certaine liberté. Cela d'autant plus que l'enceinte de leur cité est protégée par ses tours et ses murailles $^{23}$ qui, dans les représentations élisabéthaines, sont les

further action. In 1574 another proclamation appeared which was repeated with some variations in $1577,1580,1588$, and 1597 . Two schedules are appended, the first of which [...] gives the gist of the statutory restrictions on men's apparel ; while the second imposes analogous restrictions on the apparel of their wives. This extension to women indicates the growing license of feminine attire-a fact that forcibly struck a foreign observer who visited the country some years later, and provoked Stubbes to exclaim 'a ship is sooner rigged than a woman'. »

22 Reproduit dans Renaissance Tales of Desire, op. cit., p. 102.

23 Sur l'importance de ces tours et de ces murailles, voir par exemple ce que Geoffrey de Monmouth dit de Londres dans The History of the Kings of Britain, Londres, Penguin, 1966, p. 106, iii.20 : « [Lud] rebuilt the walls of the town of Trinovantum (or Troynovant) 
garantes de la sécurité du peuple en général et des femmes, en particulier.

\section{Cité et chasteté}

Dans le théâtre de Shakespeare, un certain nombre de scènes se passent aux portes de la ville ${ }^{24}$. Selon Irwin Smith, loin d'être de simples portes de coulisses, ou un rideau peint, elles constituaient des éléments du décor de certaines pièces, permettant aussi au spectateur de voir tout de suite la ligne de démarcation entre l'extérieur et l'intérieur. Voici ce qu'il explique au sujet de Henry $V$ :

Henry $V$ is yet another battle play which calls for city gates. In Act 3 , scene 3, Henry and his army stand before the Gates of Harfleur. The Governor of the town appears, presumably upon the walls. [...] The entry of the victorious English troops through the opened gates demands the emphasis and pageantry which only centrally-placed gates could give ${ }^{25}$.

Les murs de la ville encerclent la cité comme une ceinture ${ }^{26}$ enserre la taille d'une femme. Ils doivent protéger des attaques, mais laissent pourtant passer les vainqueurs. On pense dès lors à la fameuse ceinture de chasteté, objet qui n'apparaît jamais chez Shakespeare, même si l'on peut déceler la présence d'une ceinture de chasteté métaphorique dans Hamlet $^{27}$. Quand Laërte pense que l'honneur de sa sœur est menacé et qu'il lui fait part de ses inquiétudes, elle lui rétorque aussitôt qu'elle entend rester chaste : "'Tis in my memory locked, And you yourself

and girded it round with innumerable towers. He ordered the citizens to construct their homes and buildings here in such a style that no other city in the most far-flung of kingdoms could boast of palaces more fair... »

24 Irwin Smith, «'Gates' on Shakespeare's Stage », in Shakespeare Quarterly, vol. 7, $\mathrm{n}^{\circ}$ 2, printemps 1956, p. 159-76. "It is the purpose of this paper [...] to examine gate scenes in several plays, to suggest that temporary property gates were needed and that their construction was practicable, and thus to create the presumption that they existed as equipment available for use in any scene to which they were appropriate » (p. 161). 25 Ibid., p. 166.

${ }^{26}$ Le mot « ceinture », à la Renaissance, s'applique non seulement au corps mais aussi aux bâtiments. Voir par exemple la définition que Nicot donne du mot «chasteau »: « Castrum. Et est proprement ainsi appelé celuy qui a fermeture de tours et donjon au milieu, et ceinture de fossez, autrement est appelé maison plate. Mais quant aux maisons de Roy, le François courtisan les appelle toutes Chasteaux, ores que la suite des tours, donjon et fossez ne y soit ». Voir l'édition électronique de Claude Blum : Jean Nicot, Le trésor de la langue française, 1606.

${ }^{27}$ Voir Gordon Williams, A Glossary of Shakespeare's Sexual Language, Londres, Athlone, 2009, p. 192. 
shall keep the key of it » (I.iii.85). Le frère sera donc le seul à détenir la clé du «trésor » d'Ophélie ${ }^{28}$. Cette clé est pourtant bien dérisoire, car les assaillants fous de désir s'en passent aisément pour accéder au bijou qu'ils convoitent, comme le montre The Rape of Lucrece : "The locks between her chamber and his will, / Each one by him enforced retires his ward » (vers 302-03) ${ }^{29}$. La notion de fermeture ( « lock ») à l'œuvre dans Hamlet et The Rape of Lucrece se retrouve dans The Merchant of Venice où, malgré l'opposition du père de Portia, Bassanio gagne le cœur de sa bien-aimée en introduisant la clé dans la bonne serrure, celle du coffret de plomb, double symbolique de la ceinture de chasteté $^{30}$. Là encore, la référence est implicite et, de manière générale, Shakespeare emploie les mots « belt» et « chastity » sans jamais les apparier ${ }^{31}$.

L'histoire de cet objet commence avec le lai de Guigemar que Marie de France composa au cours du XII ${ }^{\mathrm{e}}$ siècle ${ }^{32}$, et qui évoque une amoureuse nouant le bas de la chemise de son compagnon tandis que ce dernier place une ceinture autour de la taille de son amante, signes que seul celui ou celle « qui sera capable de défaire la ceinture ou la chemise de couper ou briser » pourra aimer l'un ou l'autre. De cet écrit naquit le mythe de la ceinture de chasteté médiévale. Or, Marie de France ne parle pas d'une ceinture de chasteté mais d'un nœud métaphorique qui permet à deux amants de se rejoindre: seul Guigemar sera capable de défaire le nœud de la ceinture de la jeune femme qu'il aime et qui, au demeurant, est la victime d'un mariage malheureux.

\footnotetext{
${ }^{28}$ Voir Valerie Traub, Desire and Anxiety : circulations of sexuality in Shakespearean drama, Londres, Taylor \& Francis, 1992, p. 31: « Ophelia's reply [...] suggests not only that Laertes' advice is 'lock'd' in her memory, but also that Laertes alone possesses the key to her properly immured 'chaste treasure' ». On comparera l'allusion au trésor avec celle que l'on trouve dans The Rape of Lucrece, au vers 16.

29 Pour un commentaire détaillé, voir Georgianna Ziegler, « My lady's chamber : Female space, female chastity in Shakespeare » in Textual Practice, 1470-1308, volume 4, $\mathrm{n}^{\circ} 1$, printemps 1990, p. 73-90.

$3^{30}$ Voir à ce sujet l'introduction à William Shakespeare, Le Marchand de Venise, dans l'édition/traduction de François Laroque, Paris, Le Livre de Poche, Hachette Classique, 2008, p. 24.

$3^{1}$ On trouve dans Measure for Measure l'expression «a strange picklock» (III.i.285). Joseph Ritson, en 1793, y voyait une allusion à la ceinture de chasteté, mais cette lecture a été démentie par la suite, puisque « picklock» serait en réalité un équivalent de « dildo ». Voir Gordon Williams, op. cit., p. 234.

32 Marie, The Lais of Marie de France, éds. Glyn S. Burgess et Keith Busby, Londres, Penguin, 1986.
} 
Si l'on s'en réfère à Brantôme ou à Rabelais, qui les évoque sans les nommer dans Pantagruel, les ceintures de chasteté ont fait leur apparition à la Renaissance. Dans Les Vies des Dames Galantes, Pierre de Bourdeilles, abbé de Brantôme, raconte en effet l'histoire de l'arrivée de ces objets en France. Il explique que pendant le règne du roi Henri II, un marchand apporta des ceintures de chasteté à la foire de Saint-Germain. Quelques maris jaloux en achetèrent et leurs femmes se firent faire des doubles de clés, dit-il. Également appelées « ceintures de Vénus », ou « ceintures florentines», elles furent vraisemblablement créées dans les cités italiennes telles que Florence, Milan Rome ou Venise. En revanche, contrairement aux dires de Brantôme, il paraît improbable que ces ceintures aient été utilisées par des maris craignant l'infidélité de leur femme. Une gravure de Heinrich Vogtherr le jeune, exécutée vers 1540, montre d'ailleurs que la ceinture de chasteté ne restreint en rien le sexe féminin : une femme fait face au spectateur, un jeune homme et un vieillard à ses côtés ${ }^{33}$. Il s'agit en réalité d'une prostituée qui, ayant tout juste reçu de l'argent du jeune homme, le tend à son maquereau. Elle offre donc la clé à son client qui a désormais le droit de coucher avec elle.

Dans un poème gallois du XVI ${ }^{\mathrm{e}}$ siècle écrit par Sir Hywel of Builth, une jeune femme, Alice, est convoitée par le poète et par un ermite du nom de Morgan. Le poète, jaloux, va trouver un forgeron pour lui décrire par le menu une ceinture de chasteté dans l'espoir qu'il en fabrique une. Albrecht Classen a traduit ce poème en anglais, pour mieux faire ressortir l'ironie d'un discours amoureux et misogyne :

Fix against violence under a girl's smock

A case about the fettered chamber ;

Firm and low where it's not to be seen,

Strong craft of long iron ;

A new curtain over her pubic hair,

There will be a big strip over her bush.

Fix right over the lap

And make on the spot a fine shield.

$[\ldots]$

Make skillfully, with understanding yonder,

Where the pommel is, a channel to piss,

Long does all envy last,

Like pin-prick holes,

33 Voir Christa Grossinger, Picturing Women in Late Medieval and Renaissance Art, Manchester University Press, 1997, p. 96. La gravure est visible sur le site Internet: http://fr.wikipedia.org/wiki/Fichier:16thc-German-woodcut-Chastity-belt.jpg. 


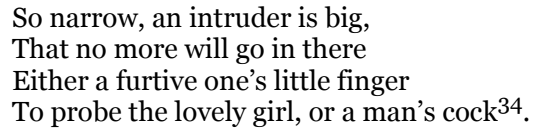

On imagine un Vulcain en herbe forger semblable bouclier, cela d'autant mieux que le dieu boiteux était lui-même trompé par Mars. On est donc dans la satire érotique, et rien ne laisse supposer qu'un tel instrument a vraiment existé. Mais on remarque au passage que, si le sexe féminin est une chambre propice à l'intimité, chambre à laquelle il faut mettre des rideaux - autrement dit une ceinture de chasteté - la femme est quant à elle une ville interdite, d'où l'intrus se doit d'être repoussé.

Le conditionnel reste de rigueur car on se rappelle Othello pour qui Chypre, citadelle que la flotte ottomane ne parvient pas même à aborder, est infiltrée sans peine par celui qui, pense-t-il, couche avec la blanche Desdémone. Le mot « citadelle » n'est d'ailleurs pas anodin puisqu'il ne fait son apparition dans la langue anglaise qu'en 1586, sous la plume de Sidney. Shakespeare emploie donc un terme récent, dont le lexicographe John Florio donne une première définition en 1598: "Citadella... a citadell, castell, or spacious fort built not onely to defend the citie, but also to keepe the same in awe and subiection ${ }^{35}$. » Chypre devrait donc imposer le respect et susciter l'effroi de ses assaillants, mais les envahisseurs imaginaires sont de redoutables passe-murailles. Les seules citadelles capables de les arrêter sont celles de la raison, une raison qui fait cruellement défaut au Maure de Venise.

On se souvient encore de Léonte, cet autre jaloux compulsif qui, dans The Winter's Tale, se plaint quant à lui que les portes d'Hermione s'ouvrent trop facilement et, surtout, contre sa volonté (« Whiles other men have gates, those gates opened, / As mine, against their will... » I.ii.195-96). Et de poursuivre ainsi ses récriminations :

34 Albrecht Classen, The Medieval Chastity Belt. A Myth-Making Process, Palgrave Macmillan, p. 129-30.

35 John Florio, A worlde of wordes, or most copious, dictionarie in Italian and English, (Londres, A. Hatfield pour E. Blount, 1598), Aldershot, Scolar Press, 1968. Le mot revient cinq fois dans Othello. On peut comparer la définition de John Florio avec celle de Randle Cotgrave en 1611 : " A Citadell; a strong Fort, or Castle, that serues both to defend, and to curbe, a citie ». Voir Randle Cotgrave, A Dictionarie of the French and English Tongues (Londres, 1611), facs., éd. William S. Woods, Columbia, The University of South Carolina Press, 1950. 
[...] Think it :

From east, west, north, and south, be it concluded, No barricado for a belly. Know't ;

It will let in and out the enemy

With bag and baggage...

(I.ii.200-04)

On est ici au plus près de l'image de la ceinture de chasteté, remarquable par son absence. Stephen Orgel explique que les premières barricades étaient constituées de barriques, et qu'elles furent érigées à Paris en 1588 lors de la "journée des barricades », au cours de laquelle Henri III fut obligé de fuir la ville, menacé qu'il était par le duc de Guise et ses nombreux alliés ${ }^{36}$. Léonte utilise donc l'image d'une ville-matrice dont il faut bloquer l'accès par des barricades. En d'autres termes, le ventre d'Hermione devrait être encerclé pour que l'ennemi n'y pénètre pas. Néanmoins, l'absence de toute ceinture de chasteté fait que l'épouse se donne au premier venu, pire, à un ami.

Cette interprétation renforcée par l'expression argotique «bag and baggage », qui renvoie aux attributs sexuels masculins. D'autre part, se trouve confirmé un passage d'All's Well That Ends Well, où le verbe « barricado » revêt cette fois un sens explicitement sexuel dans la question posée par Hélène : «Man is enemy to virginity : how may we barricado it against him ? » (I.i.114-15). Selon Gordon Williams, le mot « barricado » ne signifie ici rien d'autre que « throw up defence against (sexual) entry37. » Lorsque Shakespeare l'utilise à nouveau sous une forme nominale dans The Winter's Tale, rien n'interdit de penser qu'il garde en tête les connotations érotiques dont il l'avait affublé dans All's Well That Ends Well.

De manière significative, Hermione et son hôte Polixène se rendent dans le jardin («We are yours i’th garden» I.ii.176), ce qui attise probablement les soupçons du mari, qui allie le monde vert à une sexualité dépravée : son jardin clos et hautement civilisé devient tout à coup un hortus conclusus perverti.

Il faut dire qu'au Moyen Âge comme à la Renaissance, la tradition héroïque fait des scènes de viol des représentations par ailleurs enjolivées, dévoilant un érotisme où la nature souvent

${ }^{36}$ The Winter's Tale, éd. Stephen Orgel, op. cit., p. 106.

37 Gordon Williams, A Glossary of Shakespeare's Sexual Language, Londres, Athlone, 2009, p. 36. Susan Snyder, dans son édition, souligne la réponse de Parolles, "Keep him out » (I.i.116), qu'elle propose de gloser comme suit : « fortify yourself in a stronghold » (dans ce cas, « keep » serait à prendre dans son sens militaire). Voir William Shakespeare, All's Well That Ends Well, ed. Susan Snyder, Oxford, O.U.P., 1998, p. 85 
printanière achève d'édulcorer l'acte tout en lui donnant une allure esthétique $^{38}$.

Dans quelques cas cependant, lorsque le viol n'est pas représenté dans un cadre végétal idéalisé, il est lié aux fondations de la cité. Le viol de Lucrèce permet ainsi d'illustrer les fondements de la morale politique et familiale dans l'ancienne Rome républicaine. L'Histoire romaine de Tite-Live est la source principale de cet épisode. L'écrivain y rapporte que la jeune femme de Tarquin Collatin, membre de la famille royale, fut remarquée pour sa beauté et sa vertu par Sextus Tarquin, fils de Tarquin le Superbe, qui la viola après l'avoir menacée de déshonneur et de mort. L'épouse convoqua alors son mari et son père pour se justifier et leur fit promettre vengeance, puis se poignarda sous leurs yeux et sous ceux de Brutus. Ce dernier, ameutant la jeunesse autour du corps de Lucrèce, déclencha la révolte contre le tyran et fut avec Collatin le premier consul de la République romaine instaurée. Dès l'Antiquité, Lucrèce fut prise comme exemplum virtutis par des auteurs latins tels que Sénèque, Valère-Maxime ou Cicéron avant d'être incluse au Moyen Âge dans les séries de femmes illustres. Les hommes de la Renaissance l'insèrent même dans des frontispices on pense par exemple au De morte declamatio d'Érasme, publié à Bâle en 1518 - et la représentent sur des coffres de mariage peints, en raison de sa fidélité conjugale exemplaire.

Ce mythe trouve son apogée dans la poésie de Shakespeare qui, à l'instar de ses contemporains, usait fréquemment d'un topos modelable à l'envi pour désigner le corps de la femme assaillie, celui de la citadelle imprenable qui cède devant la force de ses conquérants. Dans The Rape of Lucrece, l'héroine, Pénélope renaissante, a beau tisser sa toile la plus intime pour renforcer sa chasteté, rien n'y fera : Tarquin, après quelques atermoiements, rompra le voile et pénétrera la cité pour une descente aussi voluptueuse que désespérée au cœur de l'enfer féminin. Et c'est en supplicié du désir qu'il y périra. Curieusement, comme le constate Katherine Duncan-Jones, sa victime semble éthérée, impalpable presque immatérielle, contrairement à la Vénus shakespearienne dont le corps transpirait, haletait et rougissait : « For a poem whose defining event is the violation of a body, Lucrece is

$3^{8}$ Voir Diane Wolfthal, «'A hue and a cry': Medieval Rape Imagery and its Transformation », The Art Bulletin, vol. 75, nº 1, mars 1993, p. 39-64 (p. 39). 
astonishingly unfleshy »39. Son corps ne s'incarne pas par la chair. Sans cesse métaphorisé, il renvoie à une réalité extérieure sur laquelle elle peut discourir et philosopher à loisir. On se souvient plus précisément de l'ekphrasis qui superpose la ville de Troie assiégée ${ }^{40}$ (avatar mythique de Londres) au corps de Lucrèce («In her the painter had anatomized / Time's ruin, beauty's wreck, and grim care's reign », v. 1450-51), alors que, dans Venus and Adonis, Shakespeare faisait correspondre les courbes de la déesse aux volutes d'un jardin de plaisir («Wishing her cheeks were garden full of flowers », v. 65) ${ }^{41}$. Lorsque Lucrèce se suicide, son corps devient une cité insulaire mise à sac par l'ennemi, dépeuplée et entourée d'une mer de sang :

$$
\begin{aligned}
& \text { And bubbling from her breast, it doth divide } \\
& \text { In two slow rivers, that the crimson blood } \\
& \text { Circles her body in on every side, } \\
& \text { Who like a late-sack'd island vastly stood } \\
& \text { Bare and unpeopled in this fearful flood. }
\end{aligned}
$$

Dans ces vers écrits aux alentours de 1594, Linda Woodbridge voit l'image de l'Angleterre mise à sac alors que, quelques années plus tôt, l'Invincible Armada menaçait en effet de mettre l'île à feu et à sang ${ }^{42}$. Cette description peut encore se lire comme le pendant négatif de deux représentations mythiques. La première est celle de la Vénus jaillie des eaux encore sanglantes car, selon Hésiode, "c'est la castration d'Uranus qui produisit l'écume de la mer [aphros] d'où sortit la céleste Aphrodite ${ }^{43}$ ». La seconde, plus floue, recouvre l'idéal de la cité insulaire que l'on retrouve dans de nombreux récits allégoriques de la Renaissance. More, Bacon et Campanella renouent le fil de la

39 Katherine Duncan-Jones, Ungentle Shakespeare. Scenes from his Life, The Arden Shakespeare, 2001, p. 76.

40 Voir vers 1429 , « strong-besiegèd Troy ».

${ }^{41}$ Voir aussi vers $232-234$.

42 Linda Woodbridge dans "Palisading the Elizabethan body politic », Texas Studies in Literature and Language, vol. 33, 1991, p. 327: "The goriness of those blood rivers, the creepiness of their "slow" movement, even the chilling vision of blood turned black through pollution, might have paled, in those immediately post-Armada days, beside the specter of a sacked island. That the woman is the island provides a clue to the impact of the Lucrece story on Elizabethans. The Rape of Lucrece, Titus Andronicus, and Cymbeline offer vivid testimony to the truth of anthropological theories that treat the human body as an image of society ".

43 Georges Didi-Huberman, Ouvrir Vénus, Paris, Gallimard, p. 45 
projection utopiste de l'Atlantide en associant étroitement les deux motifs citadin et insulaire ${ }^{44}$.

L'épouse est donc une cité dans la cité, lieu de vie où les êtres se croisent autant qu'ils se séparent. Au XVI siècle, «[1]'espace urbain obéit à une volonté de séparation et de clôture, qui donne un caractère schizé aux cités fortifiées et aux îles imaginaire ", explique ClaudeGilbert Dubois ${ }^{45}$. Les murs de la ville sont ainsi à l'origine des plus grandes tragédies amoureuses. Lorsque Tarquin les franchit pour retrouver Lucrèce seule dans sa chambre, le viol a lieu, et l'épouse déflorée souhaite alors rester dans une nuit perpétuelle que permettrait l'absence de toute ouverture laissant passer les rayons du soleil :

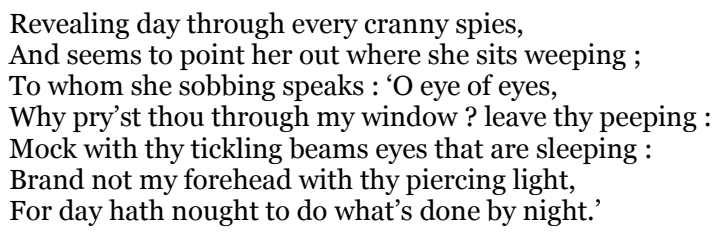

Le trou par où la lumière de l'aube entre dans la pièce est cet œil voyeur ( $\mathrm{O}$ eye of eyes »), cet $\mathrm{O}$ du désir associé par métonymie à la matrice ${ }^{46}$.

Dans l'univers de Lucrèce, il est trop tard pour colmater les brèches, celles de la cité, celle des femmes, par qui le malheur et la violence arrivent. " Long upon these terms I held my city, / Till thus he gan besiege me » (v. 176-77), soupire la jeune femme dans A Lover's Complaint : ses murailles s'écroulent, son honneur est perdu 47 . Que l'on songe encore un instant au mythe de Pyrame et Thisbé, les amants de Babylone qui échangent leurs soupirs à travers la lézarde d'un

\footnotetext{
${ }^{44}$ Sur le sujet, consulter l'ouvrage de Gilles Lapouge, Utopie et civilisations, Genève, Librairie Weber, 1973.

45 Claude-Gilbert Dubois, op. cit., p 168.

46 Dans la Bible, déjà, l'œil remplit la même fonction. « Lascivious eyes were traditionally described as doing what is normally done by sexual organs... » explique Linda Phyllis Austern dans « For, Love's a Good Musician : Performance, Audition, and Erotic Disorders in Early Modern Europe ", The Musical Quarterly, vol. 82, n $3 / 4$, Autumn-Winter 1998, p. 614-653 (p. 622). Sur l'importance du « $\mathrm{O}$ » lié au désir dans Shakespeare, voir Gordon Williams, op. cit., p. 3. L'auteur cite, outre Romeo and Juliet, un extrait du Satiromastix (1601) de Dekker : «'tis a O more more more sweet to lye with a woman » $(1,1,17)$. Voir également François Laroque, "Antoine et Cléopatre ou l'esthétique du vide ", Études Anglaises $\mathrm{n}^{\circ}$ 4, octobre-décembre 2000, p. 400-12.

47 Voir Eric Partridge, Shakespeare's Bawdy, Londres, Routledge, Routledge Classics, 2001, p. 81.
} 
mur $^{48}$. Ce mur est incarné par Snout dans A Midsummer Night's Dream, et sa faille, chez Golding comme chez Shakespeare, est à nouveau désignée par le terme "cranny » (III.i.62). Le dramaturge a également recours au mot «chink», emprunté cette fois à Thomas Mouffet 49 . Le mur fait donc à la fois obstacle à la consommation de l'amour et lui est propice précisément à cause du trou qui permet aux jeunes gens de se parler. Cette fente permet en quelque sorte une consommation métaphorique à défaut d'union charnelle, et Pyrame et Thisbé, dans le livre IV des Métamorphoses, reconnaissent d'ailleurs qu'ils doivent une fière chandelle à ce mur ébréché. Golding leur fait dire : « we think ourselves in debt ${ }^{50}$ ». Si, par définition, l'amour est une transgression, alors ce mur devient indispensable et scelle l'amour vrai. Il naît au sein de la cité (Athènes, dans A Midsummer Night's Dream, régie par un Thésée civilisateur autant que violeur notoire) et s'épanouit ou s'évanouit dans le monde vert, où nulle entrave ne vient condamner les amours illicites.

George Pettie, dans Petite Pallace of Pettie his Pleasure, fut le premier à faire un rapprochement entre l'histoire des amants de Babylone et celle de Roméo et Juliette, tenus au secret et voués à la mort ${ }^{51}$. Lorsque Shakespeare écrit Romeo and Juliet, il a donc déjà en tête l'histoire de Pyrame et Thisbé, comme l'a montré Kenneth Muir52. Le mur, invisible, est bien présent. Dans la version de Brooke, Roméo regarde ( « cast his greedy eyes ») le balcon de Juliette, et en vient à en distinguer les moindres détails, fissures comprises : «In often passing so, his busy eyes he threw, / That every pane and tooting hole the wily lover knew53 ». Vérone met les amants en présence mais ne permet pas à leur amour de se réaliser de façon concrète, ne fût-ce que pendant la nuit. Roméo ne peut donc avoir sa Juliette. Faute d'ébats amoureux au sein du lit conjugal, il déplace son ardeur au sein du combat qui

48 Ovide, Métamorphoses, IV, 55-166. On notera par ailleurs que les mots « wall » et « law» sont quasiment réversibles par effet de métathèse.

49 À comparer avec l'emploi du terme « crack » dans Cymbeline, v.vi.206-7 : « he could not / But think her bond of chastity quite cracked ».

$5^{\circ}$ Arthur Golding, Ovid's Metamorphoses translated by Arthur Golding, The Fourth Book, éd. Madeleine Forey, Penguin Books, London, 2002, p. 123, vers 95.

${ }^{51}$ Pettie remarquait «such presiness of parents brought Pyramus and Thisbe to a woful end, Romeo and Julietta to untimely death » (I. 168).

52 Kenneth Muir, «A Study in Shakespeare's Method », Shakespeare Quarterly, vol 5, ${ }^{\circ}$ 2, printemps 1954, p. 141-53.

53 Arthur Brooke, The Tragicall Historie of Romeus and Juliet, vers 440-41, in Geoffrey Bullough, éd., Narrative and Dramatic Sources of Shakespeare, 8 vols., Londres, 1957. 
l'oppose à Tybalt et qu'il gagnera. Comme l'expliquent Robert N. Watson et Stephen Dickey, "Shakespeare's contemporaries did not need Freud to help them recognize stabbing as a version of rape ${ }^{54}$ ». Et de citer Arthur Gorges en 1614 : " If they by fight away would scape, / With your sharp blades their bosomes rape 55 ». L'épée rassure l'homme sur sa virilité. Prendre une ville par l'épée revient donc bien souvent à en forcer les femmes, même si une cité comme Vérone est un corps défendant, comparable à celui de la femme qui refuse les aléas de l'amour. Ainsi, lorsque Roméo songe à sa première bien-aimée, il pense à elle comme à une cité qu'on assaille, une forteresse que les flèches d'amour n'entament pas : "She will not stay the siege of loving terms », dit-il. Il n'est qu'un Cupidon malhabile qui n'atteint jamais la chaste Diane-Rosaline.

\section{Perversités}

La cité met donc en scène deux scénarios possibles. Le premier consiste à faire de l'homme l'assaillant de la forteresse, excité par le défi que cela représente à ses yeux. Le second consiste à faire de la femme une créature consentante, qui se sert de la ville pour mieux satisfaire ses propres envies.

Le premier scénario fonctionne à merveille, même s'il n'est qu'ébauché, dans Henry $V$, où l'on se remémore ce dialogue plein de malice entre le personnage-titre et le roi de France :

KING HENRY. You may thank love for my blindness, who cannot see many a fair French city for one fair French maid that stands in my way.

KING Charles. Yes, my lord, you see them perspectively, the cities turned into a maid-for they are all girded with maiden walls that war hath never entered..

$$
\text { (v.ii.305-10) }
$$

Charles et Harry entament une négociation à propos des villes que ce dernier n'a pas, pour le moment, conquises et qui, telle Catherine, sont donc toujours vierges, mais peut-être plus pour très longtemps. Encore que, traditionnellement, la chasteté soit le trésor (« jewel») de toute

54 Robert N. Watson et Stephen Dickey, «Wherefore Art Thou Tereu ? Juliet and the Legacy of Rape ", Renaissance Quarterly, vol. 58, $\mathrm{n}^{\circ}$ 1, printemps 2005, p. 127-156 (p. 132).

55 Arthur Georges, Lucan's Pharsalia, Londres, 1614, IV.359-6o. 
jeune femme sachant faire face aux dangers qui la guettent. Mais elle est en réalité tout aussi vulnérable qu'une citadelle mal protégée, et l'intrusion est toujours à redouter.

Le second scénario, faisant de la femme un être actif, voire perverti, apparaît en filigrane dans King Lear, où les métaphores militaires sont utilisées pour dépeindre un univers féminin dévoyé au sein duquel les filles aînées du roi se conduisent comme des hommes. Regan, combattante cruelle et luxurieuse, amoureuse d'Edmond et jalouse de sa sœur, désigne l'intimité de Goneril par le biais d'une métaphore éloquente, «the forfended place» (v.i.11), qui renvoie non seulement à la matrice féminine, mais aussi au lit de l'adultère et à la citadelle aisément franchissable ${ }^{56}$. Un peu plus loin, c'est encore Regan qui se compare elle-même, cette fois, à une forteresse assiégée lorsque tout est fini pour elle. On assiste là à une ironie suprême puisque cette image, désignant habituellement la victime d'un viol, en vient à suggérer la défaite d'un bourreau :

Take thou my soldiers, prisoners, patrimony ;

Dispose of them, of me, the walls is thine.

(v.iii.76-77)

De manière tout à fait différente, ce scénario est aussi à l'œuvre dans The Changeling de Middleton et Rowley, où les créatures féminines n'ont pas froid aux yeux. Isabella désigne ainsi son labyrinthe le plus intime pour aguicher Antonio :

Stand up, thou son of Cretan Dedalus,

And let us tread the lower labyrinth ;

I'll bring thee to the clue.

(IV.iii.113-15)

Isabella est la cité de Cnossos à elle seule et, dans son dédale sensuel, elle garde jalousement son fil d'Ariane et souhaite perdre les hommes sur lesquels elle jette son dévolu ${ }^{57}$.

On trouve un autre cas de sexualité exacerbée dans The Insatiable Countess de John Marston, qui met en scène une Venise labyrinthique où se déroulent tour à tour scènes d'intérieur et d'extérieur, de sorte que le public pénètre dans les lieux intimes, les salles privées, les ruelles étroites. Au cours du deuxième acte, le

${ }^{56}$ Voir Shakespeare, King Lear, éd. R. A. Foakes, The Arden Shakespeare, (1997), 2005, p. 358. R. A. Foakes glose « forfended place » par « forbidden bed or body (of Goneril) ».

57 Voir Thomas Middleton, The Collected Works, éd. Gary Taylor et John Lavagnino, Oxford, Clarendon Press, p. 1668. 
dialogue en prose des amies d'enfance que sont Thaïs et Abigail crée par la seule magie du verbe une topologie serpentine, jonchée de passages secrets, d'ouvertures principales et d'issues arrière, de jardins clos par des barrières-obstacles. L'une des deux jeunes femmes, manigançant la ruse qui attrapera les maris jaloux en les fourvoyant dans un dédale tant spatial que mental, façonne un labyrinthe comique niché à l'intérieur même de la tragédie :

THAIS. But you mean they shall come in at the back-doors.

ABIGAIL. Who, our husbands ? Nay, and they come not in at the foredoors, there will be no pleasure in't. But we two will climb over our garden-pales, and come in that way (the chastest that are in Venice will stray for a good turn) and thus wittily will we be bestowed, you into my house to your husband, and I into your house to my husband and I warrant thee, before a month come to an end, they'll crack louder of this night's lodging than the bedsteads. (II.ii.68-76) $)^{58}$

Le thème de l'errance («stray») mêlé à celui de l'erreur inscrit les propos d'Abigail au sein du mythe du labyrinthe, prison-cité aux entrelacs multiples décrite dans les Métamorphoses d'Ovide. La parenthèse de la jeune femme («the chastest that are in Venice will stray for a good turn ») traduit bien l'ironie de la situation qui permet une sorte de mise en abyme du motif du labyrinthe dans la pièce. Elle mêle la farce et la franche obscénité dans le jeu de dupes où elle manipule les deux maris qui n'y verront que du feu, chacun croyant coucher avec l'épouse de l'autre. La plaisanterie obscène produite par la bévue de Thaïs évoque la sodomie ( «back door »), alors qu'Abigail, elle, tient à son plaisir et préfère qu'on passe par devant (« at the foredoors »59). À l'errance dans le labyrinthe de la Sérénissime et de la complexité des entrées et des sorties de la demeure, s'ajoute évidemment la (fausse) confusion sur les diverses entrées, ou pénétrations corporelles.

Si Venise incarne la dégénérescence d'une société chaotique, rongée par le mal-être et par le doute, et se trouve à ce titre au cœur du dédale créé par Marston, la cité est surtout un lieu centrifuge, dont des

$5^{8}$ John Marston, The Insatiate Countess (Londres, 1613), éd. Giorgio Melchiori, Manchester, Manchester University Press, The Revels Plays, 1984.

${ }^{59}$ Voir à ce sujet Celia R. Daileader, « Back Door Sex : Renaissance Gynosodomy, Aretino, and the Exotic ", ELH, Vol. 69, n ${ }^{\circ}$ 2, été 2002, p. 303-34. La citation de Marston est commentée p. 312. 
habitants en pleine errance cherchent à s'éloigner. C'est dans un espace inconnu, périphérique, qu'il faut aller chercher un trésor que personne ne possède, à l'image du Troyen vagabond («Trojan wanderer » II.iii.67) évoqué par Guido. Les pérégrinations de Pâris le poussèrent hors de sa contrée troyenne, certes, mais c'est à ce prix qu'il put trouver Hélène, la femme de ses rêves.

\section{Conclusion}

Aux XVI ${ }^{\mathrm{e}}$ et XVII ${ }^{\mathrm{e}}$ siècles, on constate donc avec Claude-Gilbert Dubois que le « corps est exprimé en termes d'habitation : maison, temple ou tombeau de l'âme ${ }^{60}$ ». En France, Du Bellay substitue Rome à l'aimée pétrarquéenne. Mais le corps de la cité n'est pas beau, car elle n'est en fin de compte qu'une fille de joie. En Espagne, Quevedo allie pétrarquisme et poésie des ruines à travers le mythe de Troie : pour lui, le corps en morceaux n'est qu'une ruine. Quant à Shakespeare, en misant sur le motif de la belle endormie sujette aux assauts de prétendants malhonnêtes, il invente ce qui sera l'un des topoi de la littérature gothique d'Ann Radcliffe ou de Matthew Gregory Lewis littérature nourrie des archétypes du voyeurisme, de la sensualité mortifère, et de l'image du corps-citadelle.

À la Renaissance, il existe également, pour conjurer le poids écrasant des cités maudites (Sodome, Babel, Babylone, Troie ou Carthage), des cités opulentes et maternelles comme celles décrites par d'Aubigné dans Les Tragiques :

Les villes employaient mille et mille artifices

Pour faire comme font les meilleures nourrices,

De qui le sein fécond se prodigue à l'ouvrir

Veut montrer qu'il en a pour perdre et pour nourrir.

[...] Ces villes nourricières

Prodiguaient leur substance, et en toutes manières,

Montraient au ciel serein leurs trésors enfermés,

Et leur lait et leur joie à leurs Rois bien aimés ${ }^{61}$.

On s'aperçoit encore qu'au sein des représentations artistiques en général, les scènes de viol commencent à se déplacer dans un cadre

\footnotetext{
60 Op. cit., p. 158.

${ }^{61}$ Agrippa d'Aubigné, Les Tragiques, éd. Frank Lestringant, Paris, Gallimard, 1995, I. 5698o, p. 93 .
} 
moins bucolique, plus urbain et, du même coup, l'esthétique du viol, en se faisant domestique, devient plus crue.

On observe enfin qu'avec ses allées, ses portes, ses seuils, ses passages, la cité devient l'un des réservoirs majeurs de l'imaginaire Renaissant, qui privilégie le contraste entre le monde vert et l'architecture urbaine, les pastorales et les «city comedies». Shakespeare ne néglige pas, loin de là, le thème de la cité dans son œuvre, et montre Londres sous toutes ses facettes en transportant ses pièces dans le cadre d'une géographie étrangère, exotique ou imaginaire. Il semble cependant préférer son emploi métonymique à son usage concret, comme dans le sonnet 123 :

No! Time, thou shalt not boast that I do change :

Thy pyramids, built up with newer might,

To me are nothing novel, nothing strange ;

They are but dressings of a former sight...

Selon Katherine Duncan-Jones, ces pyramides renverraient aux structures et autres arches symboliques de la cité érigées lors de l'Entrée royale de Jacques $\mathrm{I}^{\text {er }}$ à Londres, en $1604^{62}$. Un dédain semblable envers ces pyramides est exprimé dans Antoine et Cléopâtre, où Lépide, totalement ivre, y fait allusion ${ }^{63}$. Shakespeare semble mépriser cette architecture d'opulence, ponctuation suprême des villes triomphantes, qui ne lui suggère qu'une impression de déjàvu. La ville-citadelle revêt en outre un aspect irréel lorsqu'elle est associée à la virilité. Dans une pièce marquée par les images de dissolution $^{64}$, elle est, selon Antoine, un simple nuage voué à disparaître dans le ciel :

Sometimes we see a cloud that's dragonish,

A vapour sometime like a bear or lion,

A towered citadel, a pendent rock,

A forkèd mountain, or blue promontory

With trees upon't that nod unto the world

And mock our eyes with air. Thou hast seen these signs ;

They are black vesper's pageants.

\footnotetext{
${ }^{62}$ Katherine Duncan-Jones, éd. cit., p. 177. Voir aussi The Sonnets, éd. G. Blakemore Evans, Cambridge, C.U.P., The New Cambridge Shakespeare, 1996, p. 236.

63 Shakespeare, Antony and Cleopatra, II.vii.34-36: « Nay, certainly, I have heard the Ptolemies' pyramises are very goodly things. Without contradiction, I have heard that ».

64 Voir François Laroque, «Le Nil dans Antoine et Cléopâtre 》 in Le Fleuve et ses métamorphoses, Actes du colloque de l'Université Jean Moulin, Lyon III, 13-14 mai 1992. Études réunies et présentées par François Piquet, Paris, Didier Érudition, 1994, p. 437-42.
} 
Paradoxalement, c'est la ville-métaphore qui devient réelle et qui peut se conquérir. Quand Shakespeare affirme dans le sonnet 41 : "Beauteous thou art, therefore to be assailed », il rattache l'amour à la guerre, comme il le faisait déjà au début de Richard III, pour les faire se rejoindre dans un même creuset, celui du corps féminin. On retrouve un écho du sonnet 41 dans Twelfth Night, lorsque Sir Toby explique à son ami Sir Andrew comment il doit accueillir Maria : " 'Accost' is front her, board her, woo her, assail her » (I.iii.53-54) ${ }^{65}$. Pour le poètedramaturge, la femme est cette cité qui, si elle ne peut pas toujours être assaillie de force, se laisse finalement prendre par le plaisir, notion que la Renaissance met en avant et qui, au fil des siècles, sera peu à peu gommée pour être rayée de la carte à l'ère victorienne. Il n'en reste pas moins que, si l'image de la femme assiégée trouve son apogée dans le théâtre de Shakespeare par l'entremise du cliché de la citadelle imprenable, elle ne cessera de hanter les plus belles pages de la littérature. On sait par exemple que Choderlos de Laclos, auteur des Liaisons dangereuses (1782) fut officier de carrière spécialiste de la poliorcétique, c'est-à-dire de l'art d'assiéger les villes et, par voie de conséquence, de la technique de construction... des fortifications.

Sophie CHIARI

Université de Provence

\footnotetext{
65 L'OED signale d'ailleurs que le mot « assail » (« To leap upon or at, esp. with hostile intent; hence in most of its senses exactly synonymous with attack»), au sens de " courtiser », est une création shakespearienne. Voir l'entrée «Assail », 10: "To address with offers of love, to woo. Obs. c.1600 SHAKES. Sonn. xli, Beauteous thou art, therefore to be assail'd. 1601. Twel. N. I.iii.6o Accost, is, front her, boord her, woe her, assayle her. 1611 Cymb. II.iii.44, I haue assayl'd her with Musickes ».
} 